\title{
EFEKTIVITAS PENGELOLAAN KEUANGAN DESA DENGAN PENERAPAN SISTEM DAN PROSEDUR AKUNTANSI DANA DESA
}

\author{
Eko Sumarsono ${ }^{1}$ \\ Muh. Effendi Purnomo ${ }^{2}$ \\ Universitas Islam Batik Surakarta \\ efendipurnomo@yahoo.co.id ${ }^{2}$ \\ www.uniba.ac.id
}

Diterima: Februari 2019, Disetujui: Maret 2019. Dipublikasikan: April 2019

\begin{abstract}
The purpose of this study is to analyze the problems experienced by villages related to the management of village funds and also to analyze the Application of Accounting System for Village Fund Management which includes Cash Receipts, Cash Expenditures, Fixed Assets, and Taxes. This research uses descriptive qualitative method. The results show that the management is in accordance with Permendagri No.113 of 2014 and the priority of the use Village is also appropriate based on Permen Desa PDTT No. 22 of 2016, The application of accounting system is in accordance with the legislation, but if viewed from the side of administrative supervision is still not fully in accordance with the provisions, especially in the process of cash expenditures that have not been accountable and often not appropriate procedures. Therefore the author suggests that the need for a computerized accounting system so that later every accounting process can be done quickly and the output of financial statements will also be more reliable than the reporting manually, also in the future it is expected that management related to village fund can be done more accountable and transparent.

Keywords : Management of village finances, accounting information system, village fund
\end{abstract}

\begin{abstract}
Abstrak
Tujuan dari penelitian ini adalah untuk menganalisis masalah yang dialami oleh desa terkait dengan pengelolaan dana desa dan juga untuk menganalisis Penerapan Sistem Akuntansi untuk Pengelolaan Dana Desa yang meliputi Penerimaan Kas, Pengeluaran Kas, Aktiva Tetap, dan Pajak. Penelitian ini menggunakan metode deskriptif kualitatif. Hasil penelitian menunjukkan bahwa manajemen sesuai dengan Permendagri No.113 tahun 2014 dan prioritas penggunaan Desa juga sesuai berdasarkan Permen Desa PDTT No. 22 tahun 2016, Penerapan sistem akuntansi sesuai dengan undang-undang, tetapi jika dilihat dari sisi pengawasan administrasi masih belum sepenuhnya sesuai dengan ketentuan, terutama dalam proses pengeluaran uang tunai yang belum akuntabel dan seringkali prosedur yang tidak tepat. Oleh karena itu penulis menyarankan bahwa perlu adanya sistem akuntansi terkomputerisasi sehingga nantinya setiap proses akuntansi dapat dilakukan dengan cepat dan output dari laporan keuangan juga akan lebih dapat diandalkan daripada pelaporan secara manual, juga di masa depan diharapkan manajemen terkait dengan desa dana dapat dilakukan lebih akuntabel dan transparan.

Kata kunci: Pengelolaan keuangan desa, sistem informasi akuntansi, dana desa
\end{abstract}

\section{PENDAHULUAN}

Pedesaan merupakan bagian integral dari Negara Republik Indonesia. Membangun desa berarti membangun sebagian besar penduduk Indonesia, Eko (2014: 2) dikutip dalam Ismail Muhammad (2016) Menyatakan bahwa Negara berdiri mengikuti perkembangan desa atau tut wuri handayani. Hal ini mudah dimengerti karena lebih dari delapan puluh persen penduduk Indonesia tersebar di desa-desa seluruh Indonesia. 
Hoesada (2016: 231) menyatakan bahwa Pembangunan sarana prasarana desa dan dusun pada tahun-tahun yang akan datang akan meningkat secara signifikan, aparat desa akan mendapat gaji dari Negara. Brodjonegoro (2014) dikutip dalam Ismail Muhammad (2016) menyatakan bahwa Desa akan segera mendapatkan dana miliaran rupiah, Alokasi Anggaran Pendapatan dan Belanja Negara untuk desa akan selalu meningkat dari tahun ke tahun.

Berdasarkan Permendagri No. 113 Tahun 2014 Pasal 1 ayat (9), "Dana Desa adalah dana yang bersumber dari APBN yang diperuntukan bagi desa yang di transfer melalui APBD Kab/Kota yang digunakan untuk membiayai penyelenggaraan pemerintahan, pelaksanaan pembangunan, pembinaan kemasyarakatan, dan pemberdayaan masyarakat”. (BPKP 2015: 2) menyatakan bahwa dalam hal pengelolaan dana desa, akan ada risiko terjadinya kesalahan baik bersifat administratif maupun substantif yang dapat mengakibatkan terjadinya permasalahan hukum mengingat belum memadainya kompetensi kepala desa dan aparat desa dalam hal penatausahaan, pelaporan, dan pertanggungjawaban keuangan desa. Hal itu terjadi karena pemerintahan desa yang akan mendapatkan pendanaan program dan kegiatan dari berbagai sumber (APBN dan APBD Provinsi/Kabupaten) mengandung konsekuensi harus mampu mengelola secara transparan, akuntabel, dan bebas dari penyalahgunaan. Lahirnya UU No.6 Tahun 2014 tentang Pemerintahan Desa, tampaknya masih sangat membutuhkan kesiapan pelaksanaan dalam berbagai aspek yang serius. Terdapat beberapa hal yang harus disiapkan oleh desa, yaitu terkait dengan kesiapan aparatur pemerintahan desa, penerapan, dan penggunaan anggaran maupun peningkatan fungsi pelayanan masyarakatnya seiring tingginya dana yang diperoleh. Diterbitkannya UU No 6 Tahun 2014 berarti memberikan harapan baru dalam meningkatkan peran aparat pemerintah desa sebagai garda terdepan dalam pembangunan dan kemasyarakatan Indonesia. Implementasi undang undang baru akan mempengaruhi tata kelola desa, dan biasanya tidak langsung dilakukan dengan sempurna. Sehingga diperlukan kesiapan pemerintah desa agar dapat meminimalkan eksposur adanya UU yang baru.

Dalam pelaksanaan pemerintahan desa tersebut dituntut adanya suatu aspek tata pemerintahan yang baik (Good Governance), dimana salah satu karakteristik atau unsur utama dari Good Governance adalah akuntabilitas. Akuntabilitas dapat diartikan sebagai bentuk tanggungjawab pelaksanaan misi organisasi dalam mencapai tujuan yang telah 
ditetapkan melalui media pertanggungjawaban yang dilaksanakan secara periodik. Jadi, akuntabilitas pemerintahan sangat diperlukan sebagai penunjang penerapan otonomi desa agar dapat berjalan dengan baik (Putriyanti, 2012).

Pengelolaan keuangan desa, pada dasarnya dilaksanakan untuk mewujudkan desa sebagai suatu pemerintahan terdepan dan terdekat dengan rakyat,yang kuat, maju, mandiri, dan demokratis, hingga mampu melaksanakan penyelenggaraan pemerintahan dan pembangunan menuju masyarakat adil, makmur, dan sejahtera. Kajian Pengelolaan Keuangan Desayang dilakukan pada bulan Januari 2015 s.d Juni 2015, Deputi Pencegahan KPKdi Kabupaten Bogor (Jawa Barat), Kabupaten Klaten, (Jawa Tengah), Kabupaten Kampar (Riau), Kabupaten Gowa (Sulawesi Selatan), dan Kabupaten Magelang (Jawa Tengah) salah satu hasilnya adalah rencana penggunaan dan pertanggungjawaban APBDesa kurang transparan. Hal ini terlihat dari tidak adanya kewajiban bagi perangkat desa untuk mengumumkan APBDesa di awal tahun dapat mengurangi tingkat transparansi penggunaan APBDesa kepada masyarakat dan membuat masyarakat sulit dalam berpartisipasi mengawasi jalannya pembangunan di desa mereka meskipun dibeberapa tingkat provinsi maupun kabupaten/kota sebetuln ya telah banyak ditemui, seperti di Kab. Rembang, Kab. Banjarnegara, dan Kab. Malang telah mengumumkan APBD pada media informasi publik yang dapat diakses secara luas dan masyarakat dapat dengan mudah melakukan pengawasan terhadap penggunaan APBD tersebut. Keseluruhan hasil 14 temuan KPK dapat digolongkan dalam 4 aspek yaitu aspek regulasi dan kelembagaan; aspek tata laksana; aspek pengawasan; dan aspek sumber daya manusia. Subroto (2012) meneliti tentang transparansi dan akuntabilitas pengelolaan dana desa di desa-desa dalam wilayah Kecamatan Tlogomulyo Kabupaten Temanggung, hasil penelitian menunjukkan bahwa untuk perencanaan dan pelaksanaan kegiatan alokasi dana desa, sudah menampakkan adanya pengelolaan yang akuntabel dan transparan. Sedangkan dalam pertanggungjawaban dilihat secara hasil fisik sudah menunjukkan pelaksanaan yang akuntabel dan transparan, namun dari sisi administrasi masih diperlukan adanya pembinaan lebih lanjut, karena belum sepenuhnya sesuai dengan ketentuan. Kendala utamanya adalah belum efektifnya pembinaan aparat pemerintahan desa dan kompetensi sumber daya manusia, sehingga masih memerlukan pendampingan dari aparat Pemerintah Daerah secara berkelanjutan. 


\section{Identifikasi Masalah}

Permasalahan yang diprediksi muncul adalah masalah pertanggungjawaban keuangan. Seperti surat pertanggung jawaban (SPJ) yang belum memenuhi syarat formal dan material yang disebabkan kurangnya pemahaman Kepala desa dan aparatur desa akan administrasi keuangan, penyimpangan pengelolaan keuangan desa, belum lengkapnya administrasi keuangan desa sehingga inventarisasi asset desa tidak dicatat dengan baik. Sehingga masih banyak kelemahan desa yang harus dibenahi dan dipersiapkan.

Konsekuensi diberlakukannya Undang-undang RI No. 6 Tahun 2014 tentang desa pada tahun 2015 Desa yang semula hanya mendapatkan anggaran sekitar Rp.70.000.000,00 menjadi sampai Rp. 1.200.000.000,00 (Ramadhanti et al., 2015). Besarnya dana yang diperoleh desa ini berarti harus disertai pertanggungjawaban yang baik melalui akuntansi dan pelaporan keuangan. Berdasarkan penelitian yang telah dilakukan oleh Setyorini et al. (2016) menunjukkan bahwa pemahaman pelaporan keuangan desa yang transparan dan akuntabel oleh Kepala desa dan perangkat terkait UU No.6 Tahun 2014 tentang Desa, masih rendah. Tidak adanya sistem dan prosedur akuntansi pemerintahan yang built in control, serta terintegrasi antara pencatatan dana yang diperoleh melalui APBDesa maupun dari sumber lain, menjadikan penyusunan laporan pertanggung-jawaban hanya terbatas pada laporan realisasi anggaran saja. Elemen-elemen sistem pembukuan pemerintahan desa yang telah ada tidak ter-up-date ketika ada penambahan aset desa yang diperoleh dari hasil pembangunan fasilitas fisik yang diperoleh melalui APBDesa. Hal ini juga senada dengan penelitian yang dilakukan oleh Ramadhantiet al. (2016) bahwa perubahan yang signifikan dalam besarnya anggaran yang dikelola, tidak diiringi dengan sumberdaya manusia yang cakap dan handal. Sebagian besar aparatur desa berpendidikan rendah, serta kurangnya infrastruktur teknologi informasi.

\section{Tujuan Penelitian}

Tujuan penelitian ini adalah untuk mengetahui pengaruh pelatihan keuangan desa terhadap kemampuan aparatur desa dalam mengelola dana desa. Masih rendahnya pemahaman aparatur desa terkait dengan peraturan dan perundang-undangan dalam pengelolaan dana desa dapat diminimisasi dengan pelatihan pengelolaan keuangan desa. 
Pengelolaan keuangan desa mensyaratkan aparatur desa mempunyai kompetensi seperti pengetahuan, ketrampilan, sikap dan perilaku yang diperlukan dalam pelaksanaan tugasnya.

Atmadja dan Saputra (2017) menyatakan bahwa kompetensi aparatur dapat ditingkatkan melalui pelatihan, penyuluhan ataupun mengikuti diklat yang direncanakan oleh pemerintah kabupaten/kota, disamping itu untuk meningkatkan pengetahuan dan wawasan dalampengelolaan keuangan desa, aparatur dapat mengikutiworkshop, seminar ataupun kegiatan lainnya yangberkaitan dengan pengelolaan keuangan desa yangdiselenggarakan oleh lembaga-lembaga terkaitseperti BPK (Badan Pemeriksa Keuangan), IAI(Ikatan Akuntan Indonesia) atau institusi pendidikansebagai pemerhati dana desa seperti Universitasatau Institut.

\section{Kegunaan Penelitian}

Penelitian ini dapat memberikan masukan bagi aparatur desa terkait dengan peningkatan kompetensi melalui pelatihan pengelolaan keuangan desa. Peningkatan pemahaman aparatur desa terkait pengelolaan keuangan desa perlu dilakukan selain untuk tata kelola keuangan yang baik, dapat juga untuk tata kelola pemerintahan desa dan mampu berdampingan serta tidak ada asimetri informasi dengan pendamping desa yang ditugaskan oleh pemerintah pusat maupun pemerintah provinsi sehingga dapat terwujudnya laporan keuangan desa yang akuntabel dan transparan.

Kompetensi aparatur (SDM) yang memadai dari segi kuantitas dan kualitas akan meningkatkan akuntabilitas laporan realisasi anggaran di tingkat keuangan desa, sehingga segala pertanggungjawaban dapat dilakukan dengan baik dan terhindar dari segala tindak kecurangan (Atmadja dan Saputra (2017).

Bagi kebijakan publik, output penelitian dapat memberikan kontribusi dan sebagai bahan pertimbangan terhadap kebijakan terkait desa, Pelaksanaan sistem pemerintahan desa di bawah UU Desa yang baru menuntut kesiapan yang sangat baik sehingga sosialisasi, pelatihan, dan pendampingan yang terus menerus perlu dilakukan. Maka dari itu Sistem informasi akuntansi sangatlah diperlukan dalam menunjang pemerintah Desa Tincep terutama dalam menjalankan pengelolaan keuangan yang baik dan juga sesuai dengan prosedur yang semestinya agar nantinya dapat mempermudah dalam hal pelaporan dan pertanggungjawaban kepada pemerintah kabupaten dalam hal ini yang 
berkaitan dengan dana desa. Berdasarkan latar belakang masalah yang telah diuraikan, maka penulis merumuskan masalah yang akan di bahas yaitu, Bagaimana Penerapan Sistem dan prosedur Akuntansi Pengelolaan Dana Desa? Tujuan yang ingin di capai dalam penelitian ini adalah untuk mengetahui Penerapan Sistem Akuntansi dan Prosedur Pengelolaan Dana Desa

\section{TINJAUAN PUSTAKA}

American Accounting Association (AAA) menyatakan bahwa Akuntansi adalah proses identifikasi, pengukuran dan pelaporan informasi ekonomi untuk memungkinkan adanya penilaian dan keputusan yang jelas serta tegas bagi pengguna informasi tersebut. Selanjutnya Sujarweni (2015: 18) menjelaskan bahwa akuntansi pemerintahan adalah akuntansi yang bersangkutan dengan bidang keuangan negara, dari anggaran sampai dengan pelaksanaan dan pelaporannya, termasuk segala pengaruh yang ditimbulkannya. Sistem merupakan kumpulan elemen yang saling bekerja sama untuk mencapai tujuan tertentu. Susanto Azhar (2013: 22) dalam bukunya yang berjudul Sistem Informasi Akuntansi, menjelaskan bahwa Sistem adalah kumpulan/group dari sub sistem/bagian/komponen apapun baik phisik ataupun non phisik yang saling berhubungan satu sama lain dan bekerja sama secara harmonis untuk mencapai satu tujuan tertentu. Sistem ini mempunyai jaringan dan prosedur yang disusun dalam rangkaian secara menyeluruh, untuk melaksanakan berbagai kegiatan atau fungsi pokok dalam suatu badan usaha.

\section{Pengertian Sistem Akuntansi}

Mulyadi (2016; 3) menjelaskan bahwa sistem akuntansi adalah organisasi formulir, catatan, dan laporan yang di koordinasikan sedemikian rupa untuk menyediakan informasi keuangan yang dibutuhkan oleh manajemen guna memudahkan pengelolaan perusahaan. Sistem akuntansi yang dirancang dan dijalankan secara baik akan menjamin dilakukannya prinsip stewardship dan accountability dengan baik pula. Pemerintah atau unit kerja pemerintah perlu memiliki sistem akuntansi yang tidak hanya berfungsi sebagai alat pengendalian transaksi keuangan, akan tetapi sistem akuntansi tersebut hendaknya mendukung pencapaian tujuan organisasi. 


\section{Fungsi dan Tujuan Sistem Informasi Akuntansi}

Bodnart (2012: 11) dikutip dalam Tenda Stefy (2015) menyatakan bahwa Fungsi sistem informasi akuntansi yaitu bertanggungjawab untuk memproses dan mengolah data dan bertujuan untuk memperbaiki kualitas informasi, memperbaiki pengendalian internal, dan meminimalkan biaya berlebihan.

\section{Dana Desa}

Peraturan Pemerintah No. 60 Tahun 2014 tentang Dana Desa yang bersumber dari APBN menjelaskan bahwa Dana Desa adalah dana yang bersumber dari Anggaran Pendapatan dan Belanja Negara yang diperuntukkan bagi Desa yang ditransfer melalui Anggaran Pendapatan dan Belanja Daerah Kabupaten/Kota dan digunakan untuk membiayai penyelenggaraan pemerintahan, pelaksanaan pembangunan, pembinaan kemasyarakatan, dan pemberdayaan masyarakat.

\section{Pengelolaan Keuangan Desa}

Disahkannya UU No. 6 tahun 2014 tentang Desa tidak hanya merubah regulasi desa tetapi juga memberi jaminan yang lebih pasti bahwa setiap desa akan menerima dana dari pemerintah melalui anggaran negara dan daerah yang jumlahnya berlipat, jauh diatas jumlah yang selama ini tersedia dalam anggaran desa. Kebijakan ini memiliki konsekuensi terhadap proses pengelolaannya yang seharusnya dilaksanakan secara profesional, efektif dan efisien, serta akuntabel yang didasarkan pada prinsip-prinsip manejemen publik yang baik agar terhindarkan dari resiko terjadinya penyimpangan, penyelewengan dan korupsi. Desa kini mengelola dana dari berbagai sumber antara lain dana desa dari kementerian keuangan, bantuan keuangan dari pemerintah provinsi, alokasi dana desa dan bagi hasil pajak/retribusi dari pemerintah kabupaten/kota, serta bantuan dari swasta atau pihak ketiga.

Lahirnya Permendagri 113 Tahun 2014 tentang Pengelolaan Keuangan Desa diharapkan dapat menjadi pedoman bagi aparat desa agar dapat mewujudkan pengelolaan keuangan desa sesuai dengan asas transparan, akuntabel, partisipatif serta dilakukan dengan tertib dan disiplin anggaran. Berdasarkan Permendagri 113 Tahun 2014 tentang Pengelolaan Keuangan Desa dalam pasal 2 ayat (1) dijelaskan bahwa keuangan desa dikelola berdasarkan asas-asas transparan, akuntabel, partisipatif serta dilakukan dengan tertib dan disiplin anggaran. Pengelolaan keuangan desa berdasarkan pasal 1 ayat (6) 
adalah keseluruhan kegiatan yang meliputi perencanaan, pelaksanaan, penatausahaan, pelaporan, dan pertanggungjawaban keuangan desa.

Dalam pasal 3 ayat (1) dijelaskan bahwa kepala desa adalah pemegang kekuasaan pengelolaan keuangan desa dan mewakili pemerintah desa dalam kepemilikan kekayaan milik desa yang dipisahkan. Dalam pasal 3 ayat (2) lebih lanjut dijelaskan kepala desa sebagai pemegang kekuasaan pengelolaan keuangan desa sebagaimana dimaksud pada ayat (1), mempunyai kewenangan: Menetapkan kebijakan tentang pelaksanaan APBDesa; Menetapkan PTPKD; Menetapkan petugas yang melakukan pemungutan penerimaan desa; Menyetujui pengeluaran atas kegiatan yang ditetapkan dalam APBDesa; dan Melakukan tindakan yang mengakibatkan pengeluaran atas beban APBDesa. Adapun dalam melaksanakan pengelolaan keuangan desa kepala desa dibantu oleh PTPKD. Dalam pasal 4 ayat (1) dijelaskan bahwa PTPKD sebagaimana dimaksud dalam Pasal 3 ayat (3) berasal dari unsur Perangkat Desa yang terdiri dari: Sekretaris Desa; Kepala Seksi; dan Bendahara. Sekretaris Desa sebagaimana dimaksud dalam Pasal 4 ayat ( 1) huruf a bertindak selaku koordinator pelaksana teknis pengelolaan keuangan desa. Sekretaris Desa selaku koordinator pelaksana teknis pengelolaan keuangan desa sebagaimana dimaksud pada ayat (1) mempunyai tugas: Menyusun dan melaksanakan Kebijakan Pengelolaan APBDesa; Menyusun Rancangan Peraturan Desa tentang APBDesa, perubahan APBDesa dan pertanggung jawaban pelaksanaan APBDesa; Melakukan pengendalian terhadap pelaksanaan kegiatan yang telah ditetapkan dalam APBDesa; Menyusun pelaporan dan pertanggungjawaban pelaksanaan APBDesa; dan Melakukan verifikasi terhadap bukti-bukti penerimaan dan pengeluaran APBDesa. Kepala Seksi sebagaimana dimaksud dalam Pasal 4 ayat (1) huruf b bertindak sebagai pelaksana kegiatan sesuai dengan bidangnya. Kepala Seksi sebagaimana dimaksud pada ayat (1) mempunyai tugas: Menyusun rencana pelaksanaan kegiatan yang menjadi tanggung jawabnya; Melaksanakan kegiatan dan/atau bersama Lembaga Kemasyarakatan Desa yang telah ditetapkan di dalam APBDesa; Melakukan tindakan pengeluaran yang men yebabkan atas beban anggaran belanja kegiatan; Mengendalikan pelaksanaan kegiatan; Melaporkan perkembangan pelaksanaan kegiatan kepada Kepala Desa; dan Menyiapkan dokumen anggaran atas beban pengeluaran pelaksanaan kegiatan.

Bendahara sebagaimana dimaksud dalam Pasal 4 ayat (1) huruf c di jabat oleh staf pada Urusan Keuangan. Bendahara sebagaimana dimaksud pada ayat (1) mempunyai 
tugas untuk: menerima, menyimpan, menyetorkan atau membayar, menatausahakan, dan mempertanggungjawabkan penerimaan pendapatan desa dan pengeluaran pendapatan desa dalam pelaksanaan APBDesa.

\section{Pengelolaan Keuangan Desa}

Dalam Permendagri No. 113 tahun 2014, dikatakan bahwa Pengelolaan Keuangan Desa adalah keseluruhan kegiatan yang meliputi perencanaan, pelaksanaan, penatausahaan dan pertanggungjawaban keuangan desa. Namun dalam penelitian ini yang lebih difokuskan adalah pada proses pelaksanaan dan penatausahaan dana desa.

\section{Pelaksanaan}

Dalam pelaksanaan anggaran desa yang sudah ditetapkan sebelumnya timbul transaksi penerimaan dan pengeluaran desa. Semua penerimaan dan pengeluaran desa dalam rangka pelaksanaan kewenangan desa dilaksanakan melalui rekening kas desa. Jika desa yang belum memiliki pelayanan perbankan di wilayahnya maka pengaturannya ditetapkan oleh Pemerintah Kabupaten/Kota. Semua penerimaan dan pengeluaran desa harus didukung oleh bukti yang lengkap dan sah. Beberapa aturan dalam pelaksanaan pengelolaan keuangan desa sebagai berikut: Pemerintah desa dilarang melakukan pungutan sebagai penerimaan desa selain yang ditetapkan dalam peraturan desa; Bendahara dapat menyimpan uang Kas Desa pada jumlah tertentu dalam rangka memenuhi kebutuhan operasional pemerintah desa; Pengaturan jumlah uang dalam kas desa ditetapkan dalam Peraturan Bupati/Walikota; Pengeluaran desa yang mengakibatkan beban pada APBDesa tidak dapat dilakukan sebelum Rancangan Peraturan Desa tentang APBDesa ditetapkan menjadi Peraturan Desa.

Pengeluaran desa tidak termasuk untuk belanja pegawai yang bersifat mengikat dan operasional perkantoran yang ditetapkan dalam peraturan kepala desa; Penggunaan biaya tak terduga terlebih dulu harus dibuat Rincian Anggaran Biaya yang telah disahkan oleh Kepala Desa; Pelaksana kegiatan yang mengajukan pendanaan untuk melaksanakan kegiatan harus disertai dengan dokumen antara lain Rencana Anggaran Biaya; Rencana Anggaran Biaya diverifikasi oleh Sekretaris Desa dan disahkan oleh Kepala Desa; Pelaksana kegiatan bertanggungjawab terhadap tindakan pengeluaran yang menyebabkan atas beban anggaran belanja kegiatan dengan mempergunakan buku pembantu kas kegiatan sebagai pertanggungjawaban. 


\section{Penatausahaan}

Kepala desa dalam melaksanakan penatausahaan keuangan desa harus menetapkan bendahara desa. Penetapan bendahara desa harus dilakukan sebelum dimulainya tahun anggaran bersangkutan dan berdasarkan keputusan kepala desa. Ardi Hamzah dikutip oleh Sujarweni (2015) menyatakan bahwa Bendahara desa adalah perangkat desa yang ditunjuk oleh kepala desa dalam rangka pelaksanaan APBDesa. Bendahara desa wajib mempertanggungjawabkan uang melalui laporan pertanggungjawaban. Laporan pertanggungjawaban disampaikan setiap bulan kepada Kepala Desa dan paling lambat tanggal 10 bulan berikutnya. Dalam Permendagri No. 113 tahun 2014 laporan pertanggungjawaban yang wajib dibuat oleh bendahara desa adalah sebagai berikut.

a. Buku Kas Umum Buku kas umum digunakan untuk mencatat berbagai aktivitas yang menyangkut penerimaan dan pengeluaran kas, baik secara tunai maupun kredit, digunakan juga untuk mencatat mutasi perbankan atau kesalahan dalam pembukuan. Buku kas umum dapat dikatakan sebagai sumber dokumen transaksi.

b. Buku Pembantu Pajak. Buku pajak digunakan untuk membantu buku kas umum, dalam rangka penerimaan dan pengeluaran yang berhubungan dengan pajak.

c. Buku Bank. Buku bank digunakan untuk membantu buku kas umum, dalam rangka penerimaan dan pengeluaran yang berhubungan dengan uang bank.

\section{Penelitian Terdahulu}

Muhammad Ismail (2016), dengan judul : Sistem Akuntansi Pengelolaan Dana Desa. Hasil penelitian menunjukkan bahwa permasalahan utama yang timbul adalah rendahnya pengetahuan dari kepala desa terkait pengelolaan keuangan desa berdasarkan Permendagri No. 113/2014. Terdapat persamaan dari penelitian tersebut yaitu, melakukan penelitian mengenai pengelolaan keuangan desa yang berdasarkan peraturan.

Nunuk Riyani (2016), dengan judul : Analisis Pengelolaan Dana Desa (Studi Kasus Di Desa Singopuran Kecamatan Kartasura Kabupaten Sukoharjo Tahun 2016). Hasil penelitian ini menunjukan bahwa Analisis Dana Desa di Desa Singopuran Kecamatan Kartasura Kabupaten Sukoharjo sudah tersampaikan untuk pembangunan dengan baik sesuai dengan rencana namun masih ada evaluasi yang perlu diperbaiki. Terdapat persamaan dari penelitian tersebut yaitu mencari tahu apakan pengelolaan Dana Desa sudah sesuai dengan peraturan yang ada. 


\section{Perlunya Pelatihan Pengelolaan Keuangan Desa}

Perkembangan yang cukup pesat dalam pengelolaan keuangan desa baik secara jumlah dana desa yang diterima maupun pengelolaan yang menuntut akuntabilitas dan transparansi yang tinggi, tidak diimbangi dengan kompetensi aparatur desa. Beberapa penelitian membuktikan bahwa kompetensi aparatur desa masih rendah. Furqani (2010) meneliti tentang pengelolaan keuangan desa di pemerintahan Desa Kalimo Kecamatan Kalianget Kabupaten Sumenep, hasil penelitian, menunjukkan bahwa sebagian besar proses pengelolaan keuangan desa tidak memenuhi prinsip tanggung jawab karena ada beberapa hal dalam proses yang tidak sesuai dengan Permendagri Nomor 37/2007. Akuntabilitas sangat rendah karena tanggung jawab tidak melibatkan masyarakat dan BPD (Badan Permusyawaratan Desa/Badan Permusyawaratan Desa).

Hal tersebut juga selaras dengan hasil penelitian Fikri, dkk (2015) yang menyatakan bahwa kompetensi aparatur dengan pemahaman akuntansi yang kurang menyebabkan pengelolaan keuangan tidak professional sehingga berpotensi terjadi kecurangan. Dengan adanya profesionalisme dan kompetensi aparatur dalam pengelolaan keuangan desa, maka sangat diharapkan tujuan ekonomi dan sosial pemerintahan desa dapat tercapai. Oleh karena itu, peran serta pihak-pihak di luar pemerintahan desa dan Badan Permusyawaratan Desa (BPD) seperti tokoh desa, tokoh agama, kaum petani, pengusaha desa, serta perwakilan masyarakat lainnya harus bersinergi dan dilibatkan dalam pengelolaan keuangan desa (Atmadja dan Saputra,2017). Sehingga dengan demikian perlu adanya peningkatan kompetensi aparatur desa melalui pelatihan pengelolaan keuangan desa.

Salah satu faktor utama dalam meningkatkan kualitas sumber daya manusia adalah melalui pelatihan. Menurut Rivai (2004, hlm. 226) , pendidikan dan pelatihan merupakan bagian pendidikan yang menyangkut proses belajar untuk memperoleh dan meningkatkan keterampilan diluar sistem pendidikan dalam waktu relatif singkat untuk meningkatkan kinerja pegawai saat ini dan kinerja dimasa yang akan datang. Menurut hasil penelitian Hendrik (2006), bahwa pendidikan dan pelatihan (diklat) berpengaruh nyata dengan kinerja Organisasi Biro Keuangan Daerah Provinsi Sumatera Selatan. Sejalan dengan Hendrik (2006), hasil penelitian Simanungkalit (2009) menunjukkan bahwa pelatihan berpengaruh signifikan terhadap kinerja Alumni Balai Diklat Industri 
Regional I Medan. Demikian pula dengan Ayuningtyas(2012) hasil penelitiannya menunjukkan bahwa pelatihan berpengaruh terhadap pengetahuan aparatur. Hal ini disebabkan karena pelatihan memiliki hubungan dengan peningkatan pengetahuan yang dimiliki aparatur pajak.Mengikuti pelatihan bagi aparatur diharapkan semakin meningkatkan pengetahuan serta keterampilannya. Dengan demikian maka dapat dihipotesiskan bahwa:

Ha: Pelatihan pengelolaan keuangan dapat meningkatkan pemahaman aparatur desa

\section{METODE PENELITIAN}

Pendekatan penelitian ini adalah penelitian kuantitatif dengan desain pre experimental. Desain penelitian adalah semua proses yang diperlukan dalam perencanaan dan pelaksanaan penelitian. Desain penelitian yang digunakan dalam penelitian ini adalah pre eksperimenal. Penelitian eksperimen merupakan suatu cara untuk mencari hubungan sebab akibat antara dua faktor yang sengaja ditimbulkan oleh peneliti dengan mengurangi atau menyisihkan faktor- faktor lain yang mengganggu Arikunto (2010:203).

Desain penelitian ini adalah one group pretest-postest, yaitu peneliti sebelumnya memberikan pretest kepada kelompok yang akan diberikan perlakuan. Kemudian peneliti melakukan perlakuan atau treatment. Setelah selesai perlakuan, peneliti memberikan postest. Adapun teknik pengumpulan data dalam penelitian ini yaitu tes. Menurut Arikunto (2010:536), tes merupakan alat atau prosedur yang digunakan untuk mengetahui atau mengukur sesuatu dalam masalah dengan cara dan aturan-aturan yang sudah ditentukan. Pada penelitian ini tes digunakan untuk mengukur tingkat pemehaman aparatur desa terkait pengelolaan keuangan desa. Instrumen tes yang digunakan dalam penelitian ini berbentuk pilihan ganda terdiri dari 17 pertanyaan.

\section{PEMBAHASAN}

Dana desa yang telah diprogramkan oleh pemerintah tersebut harus menjadi kekuatan suatu desa dalam membangun dan mengembangkan desa tersebut agar menjadi desa yang mandiri dan kuat. Semua desa yang mendapatkan dana desa harus bisa melakukan pengelolaan keuangan desa agar bisa melaporkan dan mempertangunggajwabkan terhadap pengelolaan dana tersebut. Menurut Permendagri no 113 tahun 2014 PP 43/2014 jo PP 47/2015 yang disebut pengelolaan keuangan desa 
adalah meliputi kegiatan perencanaan, pelaksanaan, penatausahaan, pelaporan, dan pertanggungjawaban keuangan desa. Keuangan desa dikelola berdasarkan asas-asas transparan, akuntabel, partisipatif serta dilakukan dengan tertib dan disiplin anggaran Pengelolaan keuangan desa, dikelola dalam masa 1 tahun anggaran yakni mulai tanggal 1 Januari sampai dengan tanggal 31 Desember. Oleh karena itu semua perangkat desa apalagi yang bertanggungjawab mengenai dana desa tersebut harus paham mengenai pengelolaan dan pelaporan keuangan.

Penyiapan aparat desa dalam pengelolaan pembangunan desa mulai proses perencanaan, pelaksanaan/pengawasan dan pelaporan/pertanggungjawaban mutlak diperlukan. Pengelolaan pembangunan yang bersifat top down sudah tidak bisa lagi diterapkan mengingat tuntutan kemandirian desa/masyarakat didalam mencukupi kebutuhan sendiri. Kegiatan penyiapan ini berupa pengorganisasian dengan pola kegiatan seperti pelatihan pengelolaan keuangan.Pelatihan merupakan usaha untuk memperbaiki kinerja dari karyawan yang harus dilakukan secara terus-menerus untuk meningkatkan pengetahuan dan keterampilan karyawan, demi terwujudnya tujuan dari perusahaan (Ayuningtyas 2012). Hal ini sejalan dengan pemikiran dari Sudiro (2009;8), yang menyatakan bahwa salah satu cara untuk meningkatkan kualitas sumber daya manusia organisasi adalah melalui pelatihan yang dilaksanakan terencana dan sistematik.

Hal ini menunjukkan bahwa pelatihan dalam organisasi dapat meningkatkan kinerja aparatur/pegawai yang meliputi knowledge dan ketrampilan yang mendukung profesionalisme aparatur, serta pembentukan sikap setiap para aparatur sesuai yang diinginkan oleh organisasi.Hal ini juga sejalan dengan Dewi (2012) yang menyatakan bahwa pelatihan dapat meningkatkan kinerja aparatur/pegawai. Merujuk pada hasil penelitian ini yang menyatakan bahwa pelatihan dapat meningkatkan profesionalisme aparatur desa maka penguatan kapasitas tim PTPKD dan TPK Desa harus lebih sering dilakukan. Wujudnya bisa melalui pelatihan maupun bimtek. Selain itu, bisa juga dilakukan reposisi personalia pengelola keuangan desa untuk memperkuat kapasitas pengelola keuangan desa.

\section{KESIMPULAN}

Berdasar hasil penelitian dapat disimpulkan bahwa pelatihan pengelolaan keuangan desa dapat meningkatkan kompetensi dan profesionalisme aparatur desa. Sehingga perlu dilakukan pelatihan berkelanjutan terkait pengelolaan dana desa. Hal ini mengingat dana 
yang digelontorkan ke desa jumlahnya tidak sedikit. Selain itu peningkatan pemahaman akan pengelolaan keuangan desa akan mengurangi risiko penyelewengan dan ketidaktepatan penggunaan dana desa yang berakibat menjadi temuan BPK. Selain itu pelatihan pengelolaan keuangan desa yangberkelanjutan dapat membantu para aparatur desa untuk lebih update dalam menerima informasi, karena perubahan peraturan-peraturan terkait dana desa masih sering terjadi, dimana perubahan tersebut sebagai upaya untuk perbaikan implementasi pengelolaan dana desa. Setelah melakukan penelitian dengan melihat data-data dan keterangan yang diperoleh dari perangkat desa yang telah diuraikan dan dibahas pada bagian-bagian sebelumnya, maka dapat diambil kesimpulan bahwa Penerapan Sistem Akuntansi untuk Pengelolaan Dana Desa di Desa Tincep secara pencatatan sudah sesuai dengan Permendagri No. 113/2014 tentang Pengelolaan Keuangan Desa dan PMK Nomor 49/PMK.07/2016 Tentang Tatacara Pengalokasian, Penyaluran, Penggunaan, Pemantauan dan Evaluasi Dana Desa.

Meski demikian masih ada hal yang perlu lebih diperhatikan yaitu di dalam hal pengawasan administrasi terutama dalam proses pengeluaran kas yang masih belum akuntabel dan belum sesuai dengan ketentuan yang semestinya. Berdasarkan pembahasan dan kesimpulan yang dikemukakan sebelumnya maka penulis menyarankan :

1. Karena Dana Desa ini di kelola sendiri oleh pemerintah desa maka harus di pergunakan dengan baik dan di pertanggungjawabkan dengan baik khususnya dalam meningkatkan kesejahteraan masyarakat terutama dalam hal pembangunan dan pemberdayaan masyarakat yang tepat sasaran.

2. Setiap proses Akuntansi Penerimaan maupun Pengeluaran kas yang dilakukan harus selalu sesuai dengan prosedur yang semestinya dan berdasarkan undang-undang yang mengatur.

3. Perlu adanya sistem akuntansi yang lebih baik seperti misalnya sistem akuntansi yang terkomputerisasi, agar nantinya pelaporan dana desa akan mampu dilakukan dengan cepat dan output laporan keuangannnya juga akan lebih handal dibanding dengan pelaporan secara manual.

4. Pengelolaan Dana Desa perlu lebih akuntabel dan transparan.

5. Perlu adanya peningkatan kapasitas aparatur desa agar setiap komponen perangkat desa yang ada dapat lebih mengeerti dan memahami akan tugas dan tanggungjawab masing- masing. 


\section{DAFTAR PUSTAKA}

Atmadja, Anantawikrama Tungga, Komang Adi Kurniawan Saputra (2017). Pencegahan Fraud Dalam Pengelolaan Keuangan Desa. Jurnal Ilmiah Akuntansi dan Bisnis, Vol. 12, No. 1, Januari.

Ayuningtyas, Noor. 2012. Pengaruh Faktor Pendidikan, Pengalaman Kerja dan pelatihan terhadap Pengetahuan aparatur pajak Tentang Tax Avoidance. Skripsi. Universitas Brawijaya Malang.

Dewi, S,. Saka. (2012). Pengaruh Pelatihan Terhadap Kinerja Karyawan Pada PT.Sari Harta Samudra di Denpasar.

http://sistasaka.blogspot.com/2012/05/jurnal-pengaruh-pelatihan-terhadap.html?m =1 Diakses pada tanggal 14 Maret 2017.

Fikri, Ali., Biana Adha Inapty., dan Rr. Sri Pancawati Martiningsih. (2015). Pengaruh Penerapan Standar Akuntansi Pemerintahan, Kompetensi Aparatur dan Peran Audit Internal terhadap Kualitas Informasi Laporan Keuangan dengan Sistem Pengendalian Intern sebagai Variabel Moderating (Studi Empiris Pada SKPD-SKPD di Pemprov. NTB). Simposium Nasional Akuntansi XVIII, Medan.

Hendrik, 2006. Pengaruh Pendidikan dan Pelatihan (Diklat) Serta Motivasi terhadap Kinerja pegawai Sekretariat Daerah Kabupaten Tapanuli Tengah. Tesis. Tidak dipublikasikan.Sekolah Pascasarjana Universitas Siwijaya. Palembang.

Kementerian Koordinator Bidang Pembangunan Manusia dan Kebudayaan Republik Indonesia, Juni 2016. Buku Bantu Pengelolaan Pembangunan Desa, PerencanaanPenganggaran- Pengadaan Barang dan Jasa-Pelaporan-Pengawasan.

Komisi Pemberantasan Korupsi. (2015). KPK Temukan 14 Potensi Persoalan Pengelolaan Dana Desa.www.kpk.go.id. diakses tanggal 15 April 2017.

Peraturan Menteri Dalam Negeri Nomor 113 tentang Pengelolaan Keuangan Desa (Berita Negara Republik Indonesia Tahun 2014 Nomor 2093).

Peraturan Menteri Dalam Negeri Nomor 114 tentang Pedoman Pembangunan Desa (Berita Negara Republik Indonesia Tahun 2014 Nomor 2094) 
Peraturan Pemerintah Nomor 43 Tahun 2014 tentang Peraturan Pelaksanaan Undang Undang Nomor 6 tahun 2014 tentang Desa (Lembaran Negara Republik Indonesia Tahun 2014 Nomor 213, Tambahan Lembaran Negara Republik Indonesia Nomor 5539) sebagaimana telah diubah dengan Peraturan Pemerintah Nomor 47 Tahun 2015 tentang Perubahan Atas Peraturan Pemerintah Nomor 43 Tahun 2014 tentang Peraturan Pelaksanaan Undang Undang Nomor 6 tahun 2014 tentang Desa (Lembaran Negara Republik Indonesia Tahun 2015 Nomor 157, Tambahan Lembaran Negara Republik Indonesia Nomor 5717).

Putriyanti, Aprisiami., 2012., Penerapan Otonomi Desa dalam Menguatkan Akuntabilitas Pemerintahan Desa dan Pemberdayaan Masyarakat di Desa Aglik Kecamatan Grabag Kabupaten Purworejo, Skripsi UNY-Yogyakarta.

Undang-Undang Nomor 6 Tahun 2014 tentang Desa (Lembaran Negara Republik Indonesia Tahun 2014 Nomor 7, Tambahan Lembaran Negara Republik Indonesia Nomor 5495 